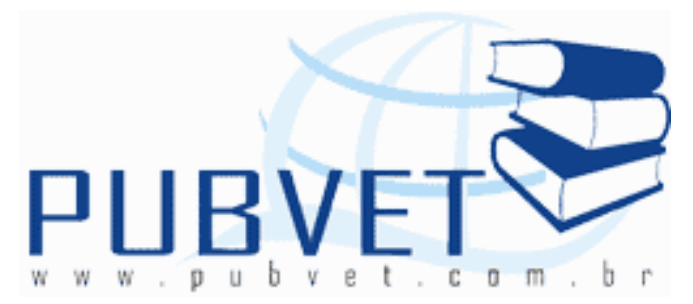

PUBVET, Publicações em Medicina Veterinária e Zootecnia.

\title{
Cistite crônica relacionada a divertículo vesico-uracal em cão Relato de caso
}

\section{Bruno Pachiega Silveira ${ }^{1}$; Ana Bárbara Freitas Rodrigues²; Ana Carolina Queiroz Lima $^{1}$; Lara Lages da Silveira ${ }^{3}$; André Lacerda Abreu Oliveira ${ }^{4}$}

1 Graduandos pela Universidade Estadual do Norte Fluminense Darcy Ribeiro (UENF) -. Av. Alberto Lamego, 2000, CEP 28013-600, Campos dos Goytacazes, RJ - E-mail: brunopachiega@hotmail.com

${ }^{2}$ Doutora em Produção Animal/ Professora de Anatomia dos Animais Domésticos LSA/CCTA/UENF.

3 Mestre em Ciência Animal pela Universidade Estadual do Norte Fluminense Darcy Ribeiro (UENF).

${ }^{4}$ Doutor em Cirurgia geral/ Professor de Técnica Cirúrgica em Pequenos Animais - LSA/ CCTA/UENF.

\section{Resumo}

Úraco é um resquício embrionário que comunica a vesícula urinária, em desenvolvimento, ao umbigo e ao saco alantóide e que tem a função de eliminar urina através da placenta. Com o pleno desenvolvimento do feto, o úraco involui e perde a sua função e a urina passa ser eliminada apenas pela uretra. Alterações decorrentes do não fechamento do canal úraco podem ser identificadas em cães, 
entre eles o divertículo vesico-uracal. Este artigo relata o caso de uma cadela, adulta, que apresentava episódios recorrentes de cistite e durante algum tempo de tratamento apresentou boa resposta à antibioticoterapia. Durante um exame ultrassonográfico foi possível observar a presença de uma vesícula urinária com parede espessa e irregular, com imagem sugestiva de cistite. Junto a esta, foi visualizada uma grande formação cística sugestivo de divertículo vesico-uracal. Durante a laparotomia exploratória o provável diagnóstico foi confirmado e procedeu-se a extirpação do segmento uracal.

Palavras-Chave: Cão; vesícula urinária; divertículo vesico-uracal

\title{
Chronic cystitis related to vesico-urachal diverticulum in dog Case report
}

\begin{abstract}
The urachal is an embryonic vestige, which announced the development in the gallbladder urinary navel and allantoic sack, with the task of eliminating urine through placental. With the full development of the fetus, urachal returns and loses its function and the urine will be eliminated only by urethra. Abnormalities related to not closing of urachal can be identified in dogs, among them the vesico-urachal diverticulum. This paper reports the case of a female dog, adult, with recurrent episodes of cystitis with good initial response with antibiotic therapy. During the ultrassonografic examination it was shown cystic training with gallbladder urinary suggesting occurrence of vesico-urachal diverticulum. During the exploratory laparotomy likely diagnosis was confirmed.
\end{abstract}

Keywords: dog, gallbladder urinary, vesico-urachal diverticulum 
SILVEIRA, B.P. et al. Cistite crônica relacionada a divertículo vesico-uracal em cão. Relato de caso. PUBVET, Londrina, V. 5, N. 19, Ed. 166, Art. 1118, 2011.

\section{INTRODUÇÃO}

O úraco é um vestígio embrionário, que comunica a vesícula urinária em desenvolvimento ao umbigo e saco alantóide, com a função de eliminar urina pela via placentária ${ }^{1}$. Com o desenvolvimento completo do feto, o úraco involui perdendo sua função e, a urina passa a ser eliminada exclusivamente pela uretra ${ }^{2,3}$.

As técnicas de diagnóstico por imagem são de grande importância para a identificação de afeç̧ões relacionadas ao sistema urogenital de pequenos animais. A grande incidência de afecções detectadas no sistema urogenital dos animais domésticos vem estimulando, cada vez mais, a utilização dessa importante ferramenta diagnóstica ${ }^{4}$.

Os sinais clínicos relacionados ao comprometimento do trato urinário inferior em cães, em especial a vesícula urinária, são: hematúria, disúria, polaciúria e incontinência urinária ${ }^{5}$. Através do exame radiográfico simples se torna fácil a detecção de alterações relacionadas ao formato, tamanho, localização e densidade da vesícula urinária. No entanto, a maioria das lesões murais e intramurais são somente identificadas com o uso de técnicas de contraste, por intermédio da cistografia ${ }^{6}$. A ultrassonografia também é considerada um método de diagnóstico por imagem bem sensível e de grande importância, pois permite que a anatomia interna do órgão seja avaliada sem a utilização de contraste e a exposição do animal à radiação ${ }^{7,8}$.

Quando a capacidade de armazenamento da vesícula urinária se torna comprometida, os transtornos funcionais podem ser graves e muitas vezes incapacitantes ${ }^{9}$. As cirurgias reconstrutivas da vesícula urinária são essenciais na correção de desordens caracterizadas pela baixa capacidade de contenção e alta pressão intravesical ${ }^{10}$. Em cães as indicações para tal cirurgia são: traumas graves, neoplasias e cistites intersticiais recorrentes. As cirurgias reconstrutivas 
SILVEIRA, B.P. et al. Cistite crônica relacionada a divertículo vesico-uracal em cão. Relato de caso. PUBVET, Londrina, V. 5, N. 19, Ed. 166, Art. 1118, 2011.

buscam promover um reservatório de baixa pressão, com capacidade de continência, micção espontânea e mínimo resíduo pós-micção ${ }^{11}$. Dentre as afecções que acometem o sistema genitourinário, podemos encontrar as primárias, aquelas que compreendem má formação congênita ou hereditária, traumas e neoplasias.

Já as afeç̧ões que são submetidas ao tratamento cirúrgico, como uma medida complementar, englobam alguns casos que não respondem ao tratamento clínico convencional, tornando-se crônicas, ou aquelas que se tornam refratárias após um período de resposta satisfatória. Como afecção cirúrgica da vesícula urinária podemos citar as anomalias do úraco.

Em humanos, as afecções referentes ao não fechamento do úraco são: a persistência do úraco, divertículo vesico-uracal, cisto e seio uracal ${ }^{12}$. A prática veterinária em pequenos animais evidencia raros relatos de afecções do sistema genitourinário relacionados com a persistência do úraco. Os potros são citados como os mais acometidos e em felino, a alteração congênita mais comum é a presença de divertículos, tendo como principal alteração a obstrução uretral ${ }^{1,13}$.

O objetivo deste trabalho foi relatar um caso de divertículo vesico-uracal relacionado à cistite crônica recorrente em cão, por se tratar de uma alteração congênita raramente vivenciada na rotina clínica de pequenos animais.

\section{MATERIAL E MÉTODOS}

Foi encaminhado ao Hospital Veterinário da Universidade Estadual do Norte Fluminense Darcy Ribeiro (UENF), Campos dos Goytacazes (RJ), uma fêmea da espécie canina, Boxer, com nove anos de idade, não castrada, apresentando história clínica de incontinência urinária, polaciúria e noctúria, O proprietário relatou episódios pregressos semelhantes com boa resposta inicial à antibioticoterapia. Ao exame físico nenhuma alteração significativa foi encontrada, exceto dois nódulos subcutâneos, que segundo proprietário havia sido diagnosticado através de punção aspirativa por agulha fina (PAAF), como 
SILVEIRA, B.P. et al. Cistite crônica relacionada a divertículo vesico-uracal em cão. Relato de caso. PUBVET, Londrina, V. 5, N. 19, Ed. 166, Art. 1118, 2011.

Lipoma. Suspeitou-se inicialmente de cistite crônica recorrente, de origem bacteriana, sendo solicitado os seguintes exames complementares: hemograma, perfil bioquímico, urinálise, e urocultura com antibiograma. O hemograma revelou discreta eosinofilia e neutrofilia. O perfil bioquímico não evidenciou alterações relevantes. A urinálise apontou a existência de grande quantidade de colônias bacterianas, que foram identificadas através de urocultura como Klebsiella pneumoniae, sendo esta resistente a alguns antibióticos como: ampicilina, cefalexina e azitromicina. Optou-se pela adminstração de norfloxacina em dose recomendada pela literatura $(20 \mathrm{mg} / \mathrm{kg})$, duas vezes ao dia, durante trinta dias. 0 animal apresentou melhora considerável durante o tratamento, tendo involução completa dos sinais clínicos inicialmente relatados.

Aproximadamente um mês após o término da terapia, o proprietário retornou e relatou que o animal apresentava sinais de prostração e melena. Diante de uma avaliação clínica primária, sem dados conclusivos, foi sugerida uma inspeção ultrassonográfica do trato digestório. Antecedendo a realização do exame, foi observado pelo proprietário que a presença de sangue nas fezes ocorreu devido à ingestão de uma massa plástica, que foi posteriormente eliminada. Mesmo assim, o animal foi encaminhado ao exame ultrassonográfico, onde toda a cavidade abdominal foi explorada e nenhuma alteração foi observada, a não ser a presença de uma vesícula urinária com parede espessa e irregular, com imagem sugestiva de cistite. Junto a esta, foi visualizada uma grande formação cística, medindo cerca de $5 \mathrm{~cm}$ de diâmetro. Foi detectada uma possível comunicação entre a vesícula urinária e a formação cística, com imagem semelhante a um oito (" 8 ") (Figura 1), diagnóstico sugestivo de divertículo vesico-uracal. 
SILVEIRA, B.P. et al. Cistite crônica relacionada a divertículo vesico-uracal em cão. Relato de caso. PUBVET, Londrina, V. 5, N. 19, Ed. 166, Art. 1118, 2011.

\section{RESULTADOS E DISCUSSÃO}

Os sinais clínicos característicos do comprometimento do trato urinário ${ }^{5}$ associados ao exame ultrassonográfico, um método de diagnóstico sensível e com capacidade de avaliação morfológica da vesícula urinária ${ }^{7,8}$, foram suficientes para uma indicação à cirurgia reparatória. ${ }^{13}$. O animal foi encaminhado ao centro cirúrgico do Hospital Veterinário/UENF para a remoção do divertículo (Figura 2). Foi realizada cirurgia reparatória através da técnica de ablação do divertículo vesico-uracal, com a extirpação do segmento uracal (Figura 3), este por sua vez apresentava um severo espessamento de parede (Figura 4). As cirurgias reparatória da vesícula urinária são essenciais na correção de algumas desordens da vesícula urinária ${ }^{10}$. Apesar de na clínica de pequenos animais serem raras as afecções do sistema genitourinário relacionadas com a persistência do úraco ${ }^{1,13}$, neste caso, portanto, pudemos observar a presença de um divertículo vesicouracal de origem primária, ${ }^{14}$ Como tratamento pós cirúrgico foi recomendado uso de Norfloxacina por trinta dias. Dois meses após a realização da cirurgia reparatória, nenhum sinal relacionado à cistite foi relatado pelo proprietário comprovando desta forma que, a vesícula urinária se tornou um reservatório de baixa pressão, com capacidade de micção espontânea e mínimo resíduo pósmicção ${ }^{11}$.

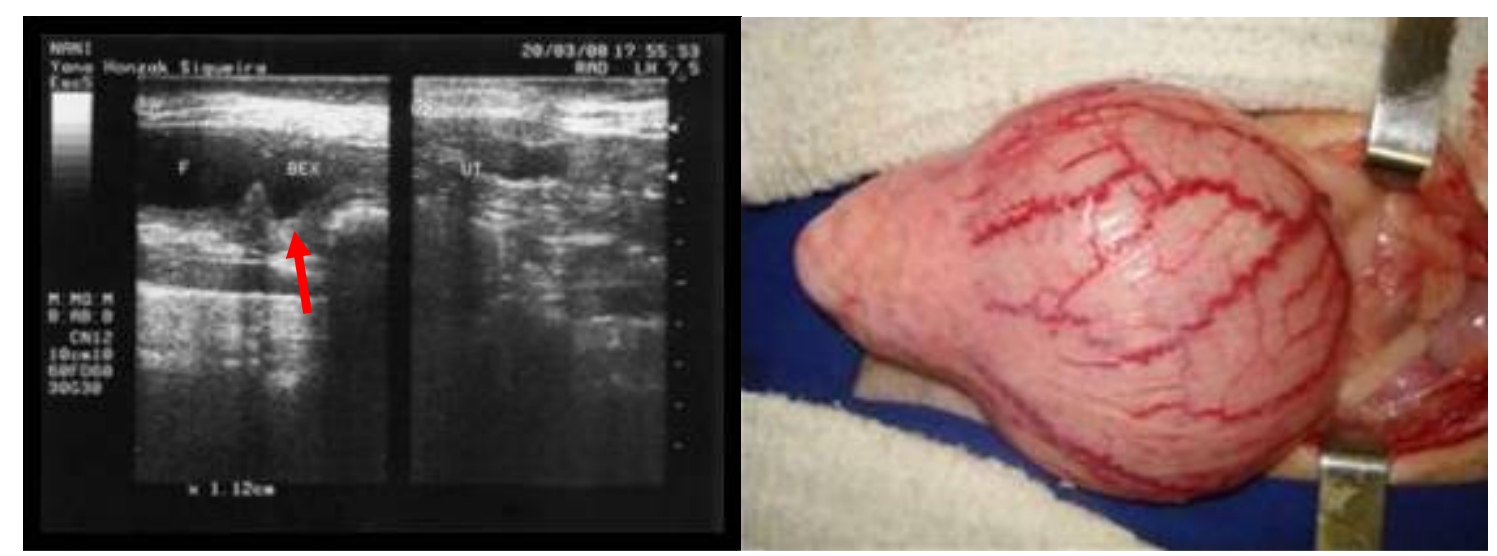

Figura 1- Imagem ultrassonográfica do Figura 2- Vesícula urinária e divertículo divertículo vesico-uracal (seta). vesico-uracal expostos durante 0 procedimento cirúrgico. 
SILVEIRA, B.P. et al. Cistite crônica relacionada a divertículo vesico-uracal em cão. Relato de caso. PUBVET, Londrina, V. 5, N. 19, Ed. 166, Art. 1118, 2011.

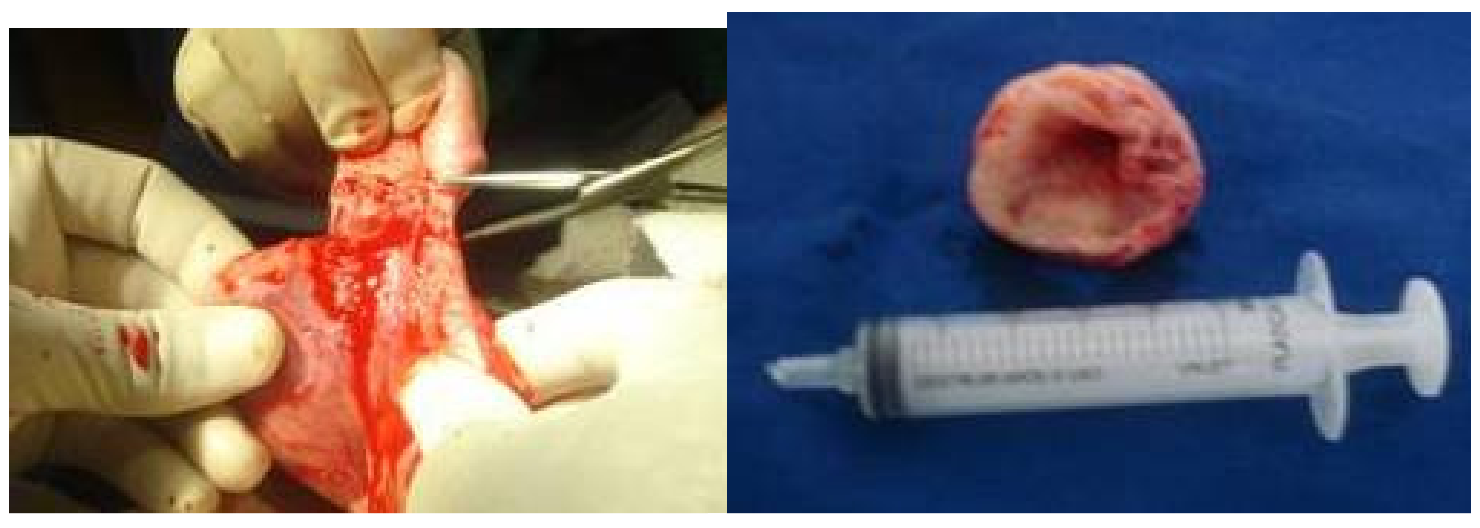

Figura 3- Cirurgia reparatória do Figura 4- Segmento uracal extirpado divertículo vesico-uracal em cão. $\quad$ apresentando espessamento de parede.

\section{REFERÊNCIAS BIBLIOGRÁFICAS :}

1.WALDRON, D.R. In: SLATTER, D. Manual de cirurgia de pequenos animais. São Paulo: Manole, 1998 , p. $1723-1736$.

2.LULICH, J.P.; OSBORNE, C.A.; BARTGES, J.W. et al. In: ETTINGER, S.J.; FELDMAN, E.C. Tratado de medicina veterinária:moléstias do cão e do gato.São Paulo: Manole, 1997, p. 2535-2573.

3.HANSEN, J.S. Vet. Med. Small Anim. Clin., 67: 379-381, 1972.

4.GALLATTI, L.B.; IWASAKI, M. Braz. J. Vet. Res. Anim. Sci., 41 (1): 40-16, 2004.

5. IWASAKI, M.; DE MARTIN, B. W. Braz. J. Vet. Res. Anim. Sci., 29 (2): 297-301, 1992 b.

6.LAMB, C. R.; The Vet. Quar., 19: 55- 56, 1997. Supplementum 1.

7.LÉVEILLÉ, R. Vet. Clin. of North Am.:Small Anim. Pra., 28 (4): 799-821, 1998.

8.BILLER, D. S. et al. J. of the Am. Anim. Hosp. Assoc., 26 (4): 397-402, 1990.

9.LEPPER, F.G.O., RAMOS, T.M., TRINDADE FILHO, J.C.S., VALE, F.R., PADOVANI, C.R., GOISSIS G. Inter. Braz. J. Urol., 28 (5): 464-470, 2002.

10.PIECHOTA, H.J., DAHMS, M.P., GLEASON, L.S, NUNES, R.D., LUE, T.F. TANAGHO, E.A. Bri. J. of Urol., 81: 548-559, 1998.

11.CRANDIS, A., NESTORIDIS, G., DELAKAS, D. et al. Bri. J. of Urol., 81 (1): 62-67, 1998.

12. ELIAS JUNIOR, A.M.; OKANO, N.; VARGAS, E.C. et al. Acta Cir. Bras., 15: 101-101, 2000.

13. BLOOD, D.C.; HENDERSON, J.A. Doença do sistema urinário. In: Medicina Veterinária. Rio de Janeiro: Guanabara Koogan, 1978, p.161-176.

14. OSBORNE, C.A.; JOHNSTON, G.R.; KRUGER, J.M.; O’BRIEN, T.D.; LULICH, L.P. Vet. Clin. of North Am.:Small Anim. Pra., 17 (3):697-773, 1987. 